\title{
Decreased Incentive Motivation Following Knockout or Acute Blockade of the Serotonin Transporter: Role of the $5-\mathrm{HT}_{2 \mathrm{C}}$ Receptor
}

\author{
Caleb J Browne ${ }^{*, 1,2}$ and Paul J Fletcher ${ }^{1,2,3}$ \\ 'Department of Psychology, University of Toronto, Toronto, ON, Canada; ${ }^{2}$ Section of Biopsychology, Centre for Addiction and Mental Health, \\ Campbell Family Mental Health Research Institute, Toronto, ON, Canada; ${ }^{3}$ Department of Psychiatry, University of Toronto, Toronto, ON, Canada
}

Acute pharmacological elevation of serotonin (5-hydroxytryptamine; 5-HT) activity decreases operant responding for primary reinforcers, suggesting that $5-\mathrm{HT}$ reduces incentive motivation. The mechanism by which 5 - $\mathrm{HT}$ alters incentive motivation is unknown, but parallel evidence that $5-\mathrm{HT}_{2 \mathrm{C}}$ receptor agonists also reduce responding for primary reinforcers implicates this receptor as a potential candidate. These experiments examined whether chronic and acute disruptions of serotonin transporter (SERT) activity altered incentive motivation, and whether the 5- $\mathrm{HT}_{2} \mathrm{C}$ receptor mediated the effects of elevated 5-HT on behavior. To assess incentive motivation, we measured responding for three different reinforcers: a primary reinforcer (saccharin), a conditioned reinforcer (CRf), and an unconditioned sensory reinforcer (USRf). In the chronic condition, responding was compared between SERT knockout (SERT-KO) mice and their wild-type littermates. In the acute condition, responding was examined in wild-type mice following treatment with 10 or 20 mg/kg citalopram, or its vehicle. The ability of the selective 5- $\mathrm{HT}_{2 \mathrm{C}}$ antagonist SB 242084 to prevent the effects of SERT-KO and citalopram on responding was subsequently examined. Both SERT-KO and citalopram reduced responding for saccharin, a CRf, and a USRf. Treatment with SB 242084 enhanced responding for a CRf and a USRf in SERT-KO mice and blocked the effects of citalopram on CRf and USRf responding. However, SB 242084 was unable to prevent the effects of SERT-KO or citalopram on responding for saccharin. These results support a powerful inhibitory function for $5-\mathrm{HT}$ in the control of incentive motivation, and indicate that the $5-\mathrm{HT}_{2 \mathrm{C}}$ receptor mediates these effects of $5-\mathrm{HT}$ in a reinforcer-dependent manner.

Neuropsychopharmacology (2016) 4I, 2566-2576; doi:I0.1038/npp.2016.63; published online 25 May 20I6

\section{INTRODUCTION}

The monoamine neurotransmitter serotonin (5-hydroxytryptamine; 5-HT) has been implicated in the control of several psychological and behavioral processes. Many lines of evidence suggest that reward-related behaviors are particularly sensitive to modulation by 5 -HT. Treatment with selective serotonin reuptake inhibitors (SSRIs) or the 5-HT releaser dexfenfluramine consistently decreases instrumental responding for primary reinforcers such as food (Thompson, 1977), drugs of abuse (Carroll et al, 1990; Richardson and Roberts, 1991), and brain stimulation reward (Lee and Kornetsky, 1998; McClelland et al, 1989). Conversely, suppression of 5-HT activity can facilitate responding for various primary reinforcers (Lyness et al, 1980; Poschel and Ninteman, 1971; Wogar et al, 1991). These findings suggest that 5-HT broadly inhibits incentive motivation-the process

* Correspondence: CJ Browne, Department of Psychology, University of Toronto, 100 St George Street, Toronto, ON, Canada M5S 3G3, Tel: + | 4I6535850I ext. 349|5, Fax: + I 416979 6942,

E-mail: Caleb.Browne@mail.utoronto.ca

Received 29 February 2016; revised 18 April 2016; accepted 24 April 2016; accepted article preview online 29 April 2016 by which motivationally significant stimuli elicit appetitive behaviors.

Through incentive motivational processes, environmental stimuli can influence goal-directed behavior. For example, environmental stimuli that are paired with the acquisition of primary reinforcers acquire motivational significance through Pavlovian conditioning. Such stimuli can elicit appetitive behaviors and support instrumental responding as conditioned reinforcers (CRfs; Taylor and Robbins, 1986). Some environmental stimuli may also possess intrinsic motivational significance, since they can support instrumental behaviors on their own in the absence of prior conditioning (Browne et al, 2016; Olsen and Winder, 2009; Stewart, 1960). These stimuli can be termed unconditioned sensory reinforcers (USRfs) to emphasize their lack of conditioned incentive value.

Whether an environmental stimulus serves as a CRf or a USRf likely depends on two separate incentive motivational processes. In the context of conditioning, a stimulus that is repeatedly presented to an animal but not paired with reward delivery does not support subsequent instrumental responding (Beninger and Ranaldi, 1992; Browne et al, 2014; Mead and Stephens, 2003). Therefore, conditioning is necessary for 
a stimulus to acquire incentive properties and serve as a CRf, while non-contingent exposure to a stimulus prevents its ability to support responding as a USRf. Rearing animals in isolation also differentially affects responding for a CRf and a USRf (Browne et al, 2016), indicating that these serve as distinct reinforcers.

The motivational significance of environmental stimuli can be altered by changes in 5-HT activity. Treatment with dexfenfluramine reduces responding for a CRf (Fletcher, 1995; Wilson et al, 2000), while whole-brain 5-HT neuron ablation enhances this behavior (Fletcher et al, 1999). In tests of drug-seeking behavior, dexfenfluramine and the SSRI fluoxetine also diminished the ability of a cocaine-paired stimulus to reinstate responding under extinction conditions (Baker et al, 2001; Burmeister et al, 2003). Furthermore, we have recently shown that another SSRI, citalopram, reduced responding for a CRf and a USRf (Browne et al, 2016). Therefore, the ability of 5-HT to suppress incentive motivation appears to extend from primary reinforcers to other types of motivationally significant stimuli.

Most of the previous studies investigating the effects of elevated 5-HT activity on motivational processes have used acute pharmacological challenges. In contrast, Sanders et al (2007) demonstrated a sustained reduction in operant responding for food following both chronic SSRI treatment and constitutive knockout of the serotonin transporter (SERT-KO), which produces a chronic, 6-fold elevation in extracellular 5-HT (Bengel et al, 1998; Fabre et al, 2000; Shen et al, 2004). These studies provide an additional line of evidence to support a major inhibitory role for 5-HT in regulating food-motivated behavior.

Serotonergic neurotransmission is mediated through multiple 5-HT receptor subtypes (Barnes and Sharp, 1999). The $5-\mathrm{HT}_{2 \mathrm{C}}$ receptor appears to have a particularly important role in regulating incentive motivation. Treatment with $5-\mathrm{HT}_{2 \mathrm{C}}$ receptor agonists attenuates operant responding for food (Grottick et al, 2000), nicotine (Fletcher et al, 2012), ethanol (Tomkins et al, 2002), cocaine (Cunningham et al, 2011; Manvich et al, 2012), and brain stimulation reward (Zeeb et al, 2015). These $5-\mathrm{HT}_{2 \mathrm{C}}$ receptor agonists also suppress cue-induced reinstatement of drug-seeking (Fletcher et al, 2012; Grottick et al, 2000; Neisewander and Acosta, 2007), and responding for CRfs (Guy and Fletcher, 2014). Therefore, 5-HT may suppress incentive motivation through $5-\mathrm{HT}_{2 \mathrm{C}}$ receptor signaling.

The present experiments had two primary objectives. The first objective was to characterize the effects of chronic and acute increases in 5-HT activity on incentive motivation elicited by three types of reinforcer. Thus, we measured operant responding for saccharin, responding for a CRf, and responding for a USRf. The second objective was to establish a mechanistic role for the $5-\mathrm{HT}_{2 \mathrm{C}}$ receptor in mediating the effects of elevated 5-HT activity. Four separate experiments were used to address these objectives. Experiments 1 and 2 examined the effects of SERT-KO and acute citalopram treatment, respectively, on responding for all three reinforcers. In Experiment 3, we examined whether the effects of SERT-KO or citalopram could be blocked by the selective $5-\mathrm{HT}_{2 \mathrm{C}}$ receptor antagonist SB 242084. Experiment 4 was conducted to confirm that SERT-KO mice exhibited a functional SERT deletion, and that the doses of citalopram used in Experiments 2 and 3 were SERT-selective.

\section{MATERIALS AND METHODS}

\section{Animals}

A total of 102 male C57BL/6 mice were used. In SERT-KO experiments, homozygous SERT null mutant mice and their wild-type (WT) littermates were used. SERT-KO mice were generated in-house through heterozygous crosses. Founder SERT-KO mice were derived from a 129 ES cell line bearing a targeted deletion of the SLC6A4 gene, which had been backcrossed to the C57BL/6J background for at least 25 generations (Jackson Laboratory, Bar Harbor, Maine). In citalopram experiments, WT C57BL/6N mice from Charles River Laboratories (Quebec, QC) were used. Responding for each type of reinforcer was examined in separate cohorts of mice. All mice were pair housed in a temperature and humidity controlled room on a 12-h light-dark cycle with lights on at $0700 \mathrm{~h}$. Throughout behavioral testing, all mice had restricted water access such that water was available for $2 \mathrm{~h}$ each day, beginning $1 \mathrm{~h}$ after completion of behavioral procedures. This ensured that mice were in the same physiological state across all tests. Food was available ad libitum. This work adhered to the guidelines of the Canadian Council on Animal Care, and protocols were approved by the Centre for Addiction and Mental Health Animal Care Committee.

\section{Apparatus}

All testing was conducted in 12 operant conditioning boxes (Med Associates, St Albans, Vermont) measuring $22 \times 18 \times 13 \mathrm{~cm}$. On the front wall of the chamber, a reinforcer magazine containing an infrared photodetector and roof-mounted light was centred $2.5 \mathrm{~cm}$ above the floor. A motor-driven dipper could be raised to deliver $0.02 \mathrm{ml}$ of liquid through a hole in the magazine floor. Two retractable levers flanked the magazine, and a yellow LED stimulus light was positioned above each lever. The box was illuminated by a houselight, and was enclosed in a sound-attenuating chamber equipped with a ventilation fan.

\section{Drugs}

Citalopram $\mathrm{HBr}$ (Toronto Research Chemicals, Toronto, Canada) was dissolved in $0.9 \%$ saline. SB 242084 (Tocris, Bristol, UK) was dissolved in a solution of $0.9 \%$ saline and $8 \%$ hydroxypropyl- $\beta$-cyclodextrin by sonication. All doses are expressed in terms of the free base. Both drugs were administered intraperitoneally in a volume of $10 \mathrm{ml} / \mathrm{kg}$. Citalopram was administered 20 min before testing while SB 242084 was administered $40 \mathrm{~min}$ before testing. Unless otherwise described, all drug treatments followed a withinsubjects design with dose order determined from a Latin Square. Drug treatment sessions were separated by $72 \mathrm{~h}$.

\section{General Behavioral Testing Procedures}

Responding for primary reinforcement. Mice were first acclimatized to water restriction for 2 weeks and were given access to a bottle containing saccharin $(0.2 \% \mathrm{w} / \mathrm{v}$ in tap water) three times for $2 \mathrm{~h}$ in their homecage to reduce neophobia during subsequent behavioral testing. Mice next underwent two daily sessions where they were trained to 
retrieve $0.02 \mathrm{ml}$ saccharin from the dipper. Here, the dipper was raised for $8 \mathrm{~s} 60$ times according to a random time (RT) 30-s schedule.

Testing. Mice were placed into operant chambers with two response levers present. Responses on the active lever could activate the dipper which remained accessible for $3 \mathrm{~s}$. Responses on the inactive lever had no programmed consequence. In 40-min sessions, mice were first trained to lever press for saccharin on a fixed-ratio 1 (FR1) schedule of reinforcement until they had acquired $>30$ saccharin presentations in two consecutive sessions. The mice were then shifted to testing phases on random ratio 2 (RR2; average number of responses required for reinforcer delivery) and RR4 schedules of reinforcement.

Responding for conditioned reinforcement. Before any behavioral procedures, mice were acclimatized to water restriction for 2 weeks, received access to saccharin three times in their homecage, and underwent two daily sessions in which they were trained to retrieve saccharin from the dipper. The conditioned reinforcement paradigm involved two phases: Pavlovian conditioning and operant conditioning. Behavioral procedures followed previously described methods (Browne et al, 2014).

Pavlovian conditioning. Mice received 14 daily 40-min sessions in which a conditioned stimulus (CS) was presented just before the delivery of saccharin 30 times on an RT 60-s schedule. The compound CS consisted of houselight off, both stimulus lights on for $5 \mathrm{~s}$, and the sound of the mechanical dipper being operated. The main dependent variables measured were head entries into the reward magazine during the 5-s CS period (before saccharin delivery) and head entries during a 5-s period just before CS onset (PreCS period).

Operant conditioning. Following Pavlovian conditioning, the ability of the CS to now support responding as a CRf was assessed. Two response levers were introduced to the operant chambers. Responding on the active lever could produce a shortened version of the CS (5-s period with the houselight off and both stimulus lights on, and an elevation of the empty dipper during the last $2 \mathrm{~s}$ ) initially on an RR2 schedule of reinforcement. Responding on the inactive lever had no programmed consequence. The first session of this phase lasted until 10 active lever responses were made or after $40 \mathrm{~min}$ elapsed. This session served to familiarize mice with the response levers and minimize confounding novelty on the subsequent test days (Fletcher, 1995; Kelley and Delfs, 1991). Data from this session were not presented. Each subsequent test was carried out in 40-min sessions with no limits on responding.

Responding for unconditioned sensory reinforcement. Mice were acclimatized to water restriction for 2 weeks before tests of responding for a USRf. Behavioral procedures followed previously described methods (Browne et al, 2016).

Testing. Mice naive to behavioral testing were placed in operant chambers with two response levers presented. Responding on the active lever could produce the USRf: 5-s stimulus compound consisting of houselight off, both yellow stimulus lights on for $5 \mathrm{~s}$, and the sound of the dipper during the last $2 \mathrm{~s}$. This stimulus compound was chosen to be exactly the same as the stimulus serving as a CRf, but the dipper was always empty. Responding on the inactive lever had no programmed consequence. Each test session lasted $60 \mathrm{~min}$. Mice first acquired responding on an FR1 schedule of reinforcement for six sessions, and this was changed to an RR2 schedule for the remainder of testing.

\section{Experiment 1: Responding for Saccharin, a CRf, and a USRf in SERT-KO Mice}

Responding for saccharin. SERT-KO mice $(n=12)$ and WT littermates $(n=12)$ were first tested on an RR2 schedule of reinforcement for five sessions, followed by five sessions on an RR4 schedule.

Responding for a CRf. During Pavlovian conditioning, approach to the reward magazine across 14 sessions was compared between SERT-KO mice $(n=11)$ and WT littermates $(n=10)$. In the operant conditioning phase, responding for the CS serving as a CRf was compared between genotypes on an RR2 schedule of reinforcement for three sessions followed by an RR4 schedule for three more sessions.

Responding for a USRf. SERT-KO mice $(n=12)$ and WT littermates $(n=12)$ received six acquisition sessions on an FR1 schedule of reinforcement, followed by seven test sessions on an RR2 schedule.

\section{Experiment 2: Responding for Saccharin, a CRf, and USRf-Effects of Acute Citalopram}

Responding for saccharin. Mice $(n=10)$ first underwent baseline testing for five sessions on both RR2 and RR4 schedules of reinforcement. Subsequently, the effect of 10 and $20 \mathrm{mg} / \mathrm{kg}$ citalopram and its vehicle was tested over three more sessions on the RR4 schedule.

Responding for a CRf. Following Pavlovian conditioning, mice $(n=12)$ received four baseline sessions of responding for a CRf on an RR2 schedule of reinforcement (data not shown). The effect of 10 and $20 \mathrm{mg} / \mathrm{kg}$ citalopram and its vehicle was then tested over three more sessions on the RR2 schedule.

Responding for a USRf. Mice $(n=12)$ first acquired responding for a USRf on an FR1 schedule of reinforcement over six sessions followed by seven more sessions on an RR2 schedule. Subsequently, the effect of 10 and $20 \mathrm{mg} / \mathrm{kg}$ citalopram and its vehicle was tested over three more sessions on the RR2 schedule.

\section{Experiment 3: Role of the 5- $\mathrm{HT}_{2 \mathrm{C}}$ Receptor in Mediating the Effects of SERT-KO and Citalopram on Operant Responding}

Responding for saccharin. Responding on an RR4 schedule of reinforcement was compared between SERT-KO mice and WT littermates following treatment with $1 \mathrm{mg} / \mathrm{kg}$ SB 242084 
or its vehicle. In the citalopram condition, mice were treated with $1 \mathrm{mg} / \mathrm{kg} \mathrm{SB} 242084$ or its vehicle before $10 \mathrm{mg} / \mathrm{kg}$ citalopram or its vehicle (four treatment conditions) and tested on an RR4 schedule of reinforcement.

Responding for a CRf. Responding on an RR4 schedule of reinforcement was compared between SERT-KO mice and WT littermates following treatment with $1 \mathrm{mg} / \mathrm{kg} \mathrm{SB} 242084$ or its vehicle. Here, $1 \mathrm{mg} / \mathrm{kg}$ SB 242084 did not significantly alter responding in WT mice. However, in mice used for the citalopram study, we found that this dose of SB 242084 significantly elevated responding above control levels (data not shown). For this reason, mice were treated with $0.25 \mathrm{mg} / \mathrm{kg}$ SB 242084 or its vehicle before $10 \mathrm{mg} / \mathrm{kg}$ citalopram or its vehicle (four treatment conditions) and tested on the RR2 schedule of reinforcement.

Responding for a USRf. We had concerns that SERT-KO mice may not have acquired the behavior well enough for a single SB 242084 challenge to alter responding. Therefore, we used a repeated treatment design wherein SERT-KO mice and WT littermates were tested for three sessions with vehicle, and then five sessions with $1 \mathrm{mg} / \mathrm{kg} \mathrm{SB} 242084$. In the citalopram condition, mice were treated with $1 \mathrm{mg} / \mathrm{kg} \mathrm{SB}$ 242084 or its vehicle before $10 \mathrm{mg} / \mathrm{kg}$ citalopram or its vehicle (four treatment conditions) and tested on the RR2 schedule of reinforcement.

\section{Experiment 4: Confirmation of SERT-KO and SERT-Selective Doses of Citalopram}

In SERT-KO mice and WT littermates, the effects of 10 and $20 \mathrm{mg} / \mathrm{kg}$ citalopram or its vehicle on responding for saccharin (RR4 schedule of reinforcement), a CRf (RR2 schedule), and a USRf (RR2 schedule) were examined.

\section{Data Analysis}

Statistical analyses were performed using Statistica (v7). Data were analyzed using two- and three-way repeated measures ANOVAs, with Session, CSvsPreCS (Pavlovian conditioning), Lever (active or inactive), Dose, or Treatment (in pharmacological blocking experiments) as within-subject measures and Genotype as a between-subjects measure when applicable. In Experiment 3, data for SERT-KO mice and WT littermates were analyzed separately as we hypothesized that SB 242084 treatment would produce changes in operant responding in SERT-KO mice but not in WT littermates. Where repeated SB 242084 treatment was used in Experiment 3, separate ANOVAs were conducted across vehicle or SB 242084 conditions for SERT-KO mice and WT littermates. No significant main effect of session was observed in any case. Therefore, ANOVAs were conducted using means averaged across the three vehicle and five SB 242084 treatment sessions. Post hoc pairwise comparisons were performed using the Tukey's honest significant difference test. Significance was set at $p<0.05$ for all analyses.

\section{RESULTS}

\section{Experiment 1: Responding for Saccharin, a CRf, and a USRf in SERT-KO Mice}

Responding for saccharin. Responding was similar between SERT-KO mice and WT littermates on an RR2 schedule of reinforcement (Figure 1a; Genotype: $\mathrm{F}_{(1,22)}=1.99$, ns). However, SERT-KO mice made fewer active lever responses on the more demanding RR4 schedule (Figure 1b; Genotype $\times$ Lever: $\mathrm{F}_{(1,22)}=4.76, p<0.05$; Genotype: $\left.\mathrm{F}_{(1,22)}=10.12, p<0.01\right)$.

Responding for a CRf. During Pavlovian conditioning, SERT-KO mice and WT littermates showed similar rates of learned approach to the reward magazine upon CS presentation (Figure 1c; CSvsPreCS $\times$ Session: $\mathrm{F}_{(13,247)}$ $=14.61, p<0.001$; Genotype: $\mathrm{F}_{(1,19)}=0.13$, ns). However, in the operant conditioning phase, SERT-KO mice made fewer responses for the CRf compared with WT littermates (Figure 1d). This effect was moderate at the RR2 schedule (Genotype: $\mathrm{F}_{(1,19)}=3.44, p=0.079$ ), but reached statistical significance on the more demanding RR4 schedule (Genotype: $\left.\mathrm{F}_{(1,19)}=6.51, p<0.05\right)$.

Responding for a USRf. SERT-KO mice made significantly fewer responses for a USRf compared with WT littermates on both FR1 (Figure 1e; Genotype: $\mathrm{F}_{(1,22)}=5.36$, $p<0.05$ ) and RR2 (Figure 1f; Genotype $\times$ Lever: $\mathrm{F}_{(1,22)}=8.71$, $p<0.01$; Genotype: $\left.\mathrm{F}_{(1,22)}=14.47, p<0.001\right)$ schedules of reinforcement.

\section{Experiment 2: Responding for Saccharin, a CRf, and USRf-Effects of Acute Citalopram}

Responding for saccharin. Mice acquired stable responding on RR2 and RR4 schedules of reinforcement (Figure 2a; Lever: $\left.\mathrm{F}_{(1,9)}>84.10, p<0.001\right)$, and citalopram decreased active lever responding on the RR4 schedule (Figure 2b; Dose $\times$ Lever: $\left.\mathrm{F}_{(2,18)}=22.27, p<0.001\right)$. Post hoc tests confirmed that 10 and $20 \mathrm{mg} / \mathrm{kg}$ doses decreased active lever responses compared with vehicle (both $p<0.001$ ).

Responding for a CRf. During Pavlovian conditioning, mice learned to approach the reward magazine upon CS presentation (Figure 2c; Session $\times$ CSvPreCS: $\mathrm{F}_{(1,13)}=18.11, p<0.001$ ). In the operant conditioning phase, mice selectively responded for the CRf over four baseline sessions (data not shown; Lever: $\left.\mathrm{F}_{(1,11)}=20.28, p<0.001\right)$. Citalopram significantly decreased responding for the CRf (Figure $2 \mathrm{~d}$; Dose $\times$ Lever: $\mathrm{F}_{(2,22)}=$ 15.52, $p<0.001$ ) at both 10 and $20 \mathrm{mg} / \mathrm{kg}$ doses compared with vehicle (both $p<0.001$ ).

Responding for a USRf. Mice made more responses on the active lever compared with the inactive lever on both FR1 $\left(\mathrm{F}_{(1,11)}=11.43, p<0.01\right)$ and $\mathrm{RR} 2\left(\mathrm{~F}_{(1,11)}=7.64, p<0.05\right)$ schedules of reinforcement (Figure 2e). Citalopram significantly decreased responding for the USRf on the RR2 schedule (Figure 2f; Dose $\times$ Lever: $\mathrm{F}_{(2,22)}=8.02, p<0.01$ ) at both the $10-$ and $20-\mathrm{mg} / \mathrm{kg}$ doses compared with vehicle (both $p<0.001$; Figure 2f). 


\section{Experiment 3: Role of the 5- $\mathrm{HT}_{2 \mathrm{C}}$ Receptor in Mediating the Effects of SERT-KO and Citalopram on Operant Responding}

Responding for saccharin. Treatment with $1 \mathrm{mg} / \mathrm{kg} \mathrm{SB}$ 242084 had no effect in either SERT-KO mice (Figure 3a; Dose: $\mathrm{F}_{(1,11)}=0.24, p>0.05$ ) or $\mathrm{WT}$ littermates (Dose: $\left.\mathrm{F}_{(1,11)}=0.16, p>0.05\right)$. Similarly, $1 \mathrm{mg} / \mathrm{kg}$ SB 242084 did not completely block the ability of $10 \mathrm{mg} / \mathrm{kg}$ citalopram to reduce responding (Figure 3b). The citalopram-SB 242084 condition was not significantly different from vehicle-vehicle, but was also not significantly different from vehicle-citalopram (both $p>0.05)$.

Responding for a CRf. Treatment with $1 \mathrm{mg} / \mathrm{kg}$ SB 242084 increased active lever responding in SERT-KO mice by 95\% (Figure 3c; Treatment $\times$ Lever: $\mathrm{F}_{(1,10)}=10.37, p<0.01$;
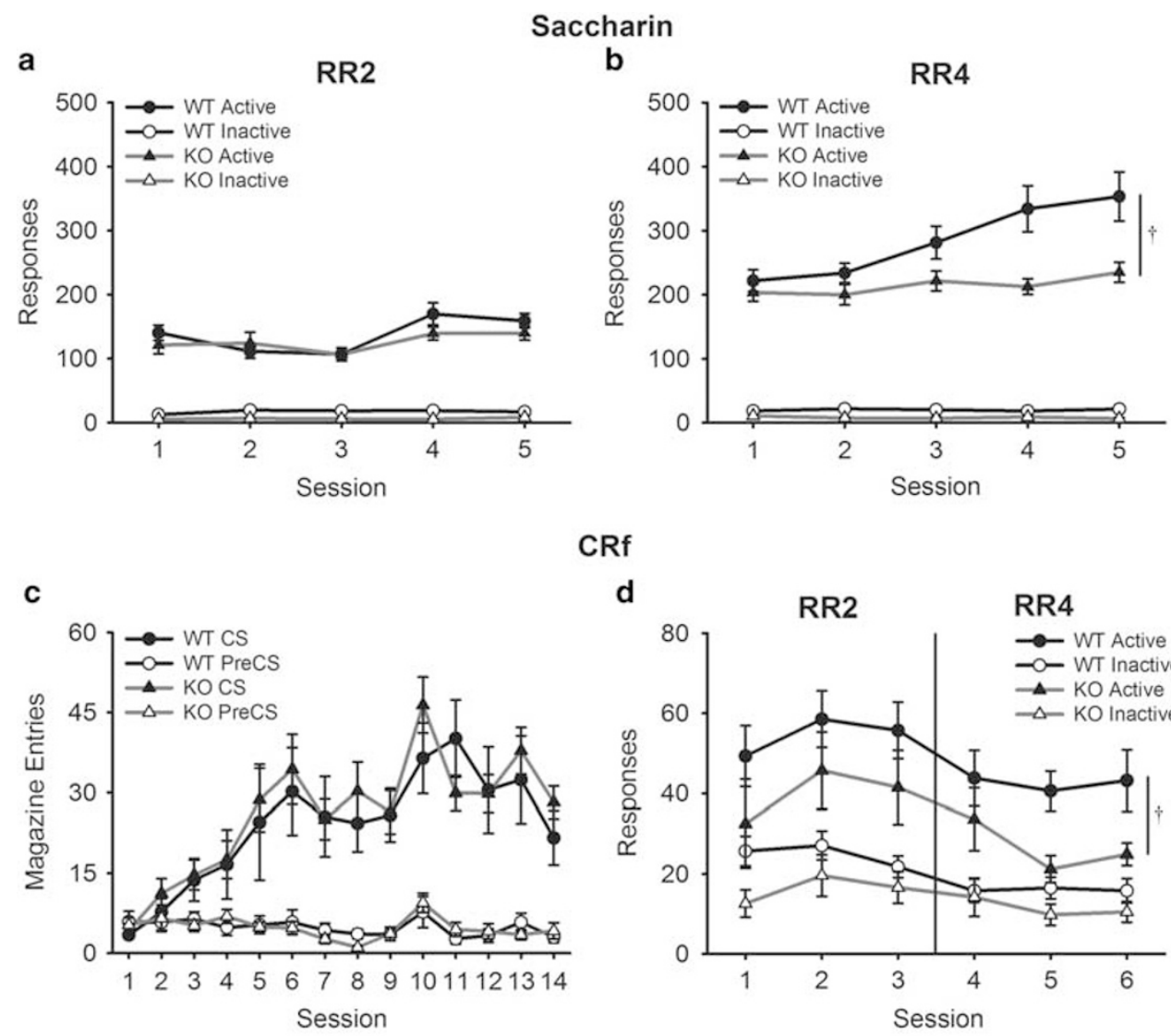

CRf

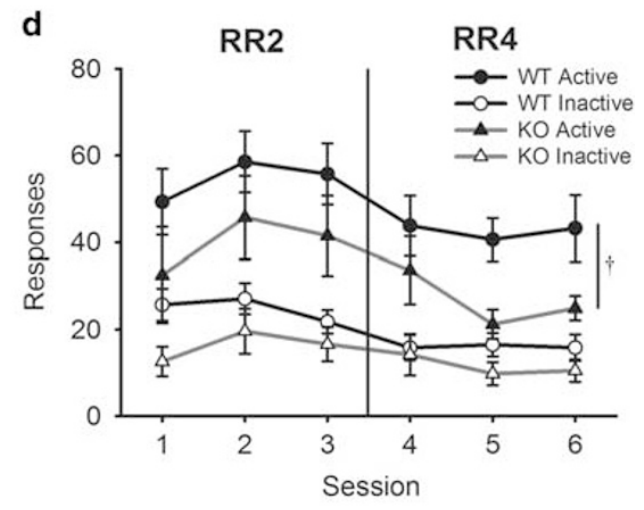

USRf

e

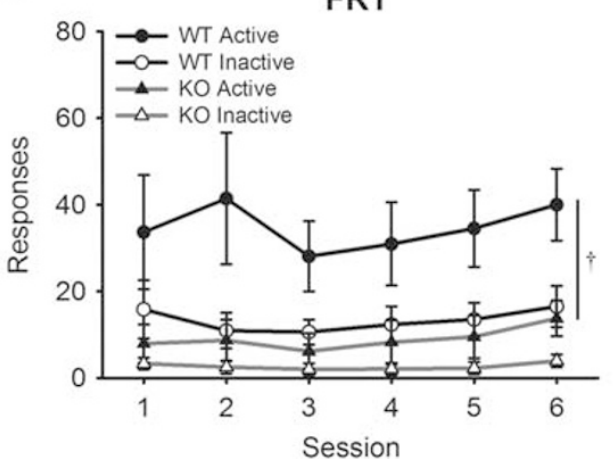

f

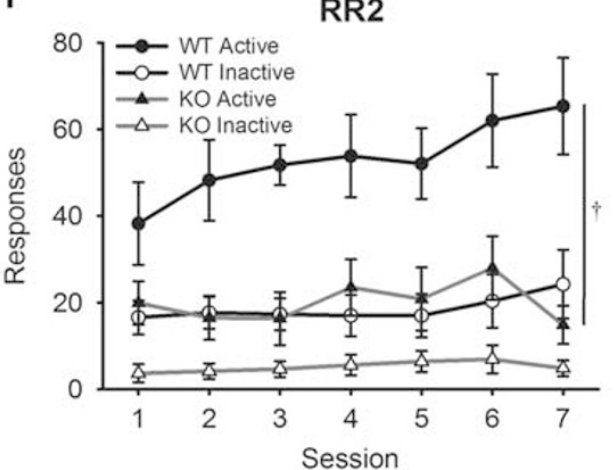

Figure I SERT-KO reduces responding for saccharin, a conditioned reinforcer (CRf), and an unconditioned sensory reinforcer (USRf). (a and b) Responses made on the active lever delivering saccharin (filled symbols) and the inactive lever (empty symbols) by SERT-KO mice (gray lines; $n=12$ ) and WT littermates (black lines; $n=12$ ) on random ratio 2 (RR2) and RR4 schedules of reinforcement. (c) Reward magazine entries made by SERT-KO mice ( $n=1$ I) and WT littermates $(n=10)$ during the 5-s CS presentation before saccharin delivery (CS; filled symbols) or a 5-s period just before CS onset (Pre-CS; empty symbols) in the Pavlovian conditioning phase of the conditioned reinforcement procedure. (d) Responding on a lever delivering the CS now serving as a CRf (active lever; filled symbols) and an inactive lever (empty symbols) by SERT-KO and WT mice on RR2 and RR4 schedules of reinforcement. (e and $f$ ) Responses made on the active lever delivering the USRf (filled symbols) and the inactive lever (empty symbols) by SERT-KO mice $(n=12)$ and WT littermates $(n=12)$ on FRI and RR2 schedules of reinforcement. Data are expressed in terms of the mean \pm SEM. ${ }^{\dagger} P<0.05$ main effect of Genotype. 
a

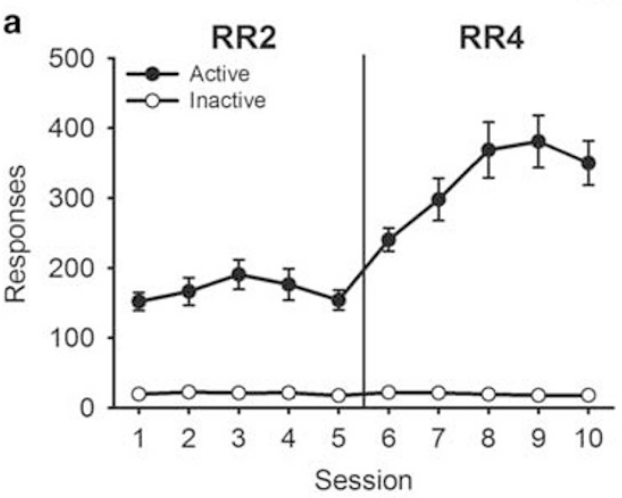

C

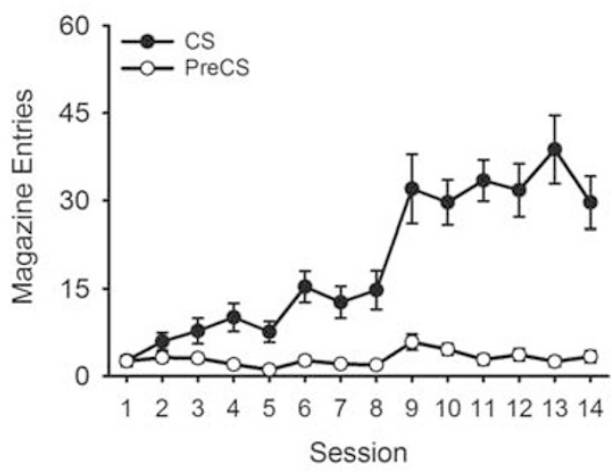

\section{Saccharin}

b



CRf

$$
\text { d }
$$

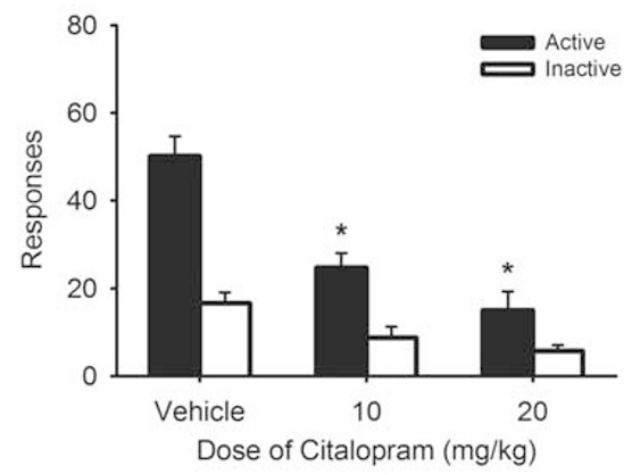

USRf

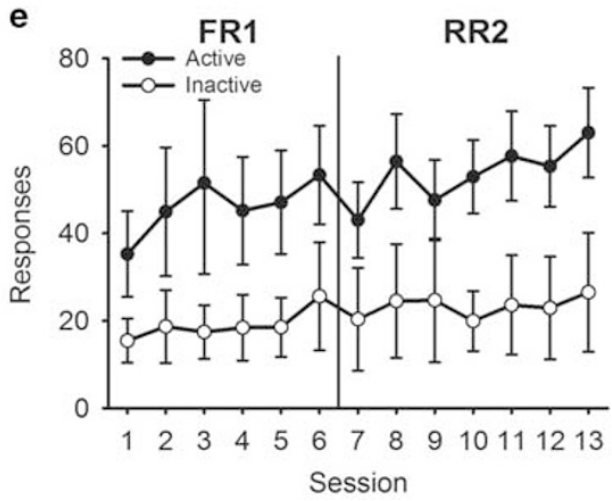

f

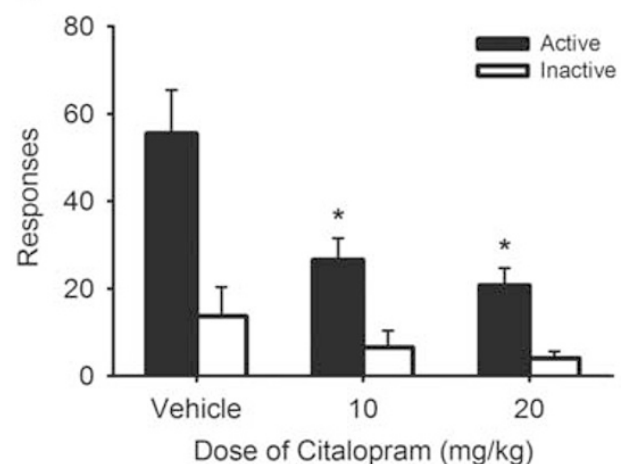

Figure 2 Acute citalopram treatment reduces responding for saccharin, a conditioned reinforcer (CRf), and an unconditioned sensory reinforcer (USRf). ( $\mathrm{a}$ and b) Responses made by WT mice $(n=10)$ on the active lever delivering saccharin (filled symbols and bars) or the inactive lever (empty symbols and bars) under baseline conditions (a), and following treatment with 10 and $20 \mathrm{mg} / \mathrm{kg}$ citalopram or its vehicle on the RR4 schedule (b). (c) Reward magazine entries made by WT mice $(n=12)$ during the 5-s CS presentation before saccharin delivery (CS; filled symbols) or a 5-s period just before CS onset (Pre-CS; open circles) in the Pavlovian conditioning phase of the conditioned reinforcement procedure. (d) Responding on a lever delivering the CS now serving as a CRf (active lever; filled symbols) and the inactive lever (empty symbols) by WT mice on an RR2 schedule of reinforcement following treatment with 10 and $20 \mathrm{mg} / \mathrm{kg}$ citalopram or its vehicle. (e and f) Responses made on the active lever delivering the USRf (filled symbols and bars) and the inactive lever (empty symbols and bars) by WT mice $(n=12)$ at baseline on FRI and RR2 schedules of reinforcement (e), and on the RR2 schedule following treatment with 10 and $20 \mathrm{mg} / \mathrm{kg}$ citalopram or its vehicle (f). Data are expressed in terms of the mean \pm SEM. $* P<0.05$ vs vehicle.

Treatment: $\left.F_{(1,10)}=6.20, p<0.05\right)$, but had no effect in WT littermates (Treatment $\times$ Lever: $\mathrm{F}_{(1,9)}=1.70$, ns; Treatment: $F_{(1,9)}=2.87$, ns). Similarly, $0.25 \mathrm{mg} / \mathrm{kg}$ SB 242084 blocked the inhibitory effects of citalopram on responding (Figure 3d). The SB 242084-citalopram condition was significantly different from vehicle-citalopram $(p<0.001)$, but not vehicle-vehicle $(p>0.80)$.

Responding for a USRf. Data from repeated treatment conditions were averaged across vehicle and SB 242084 

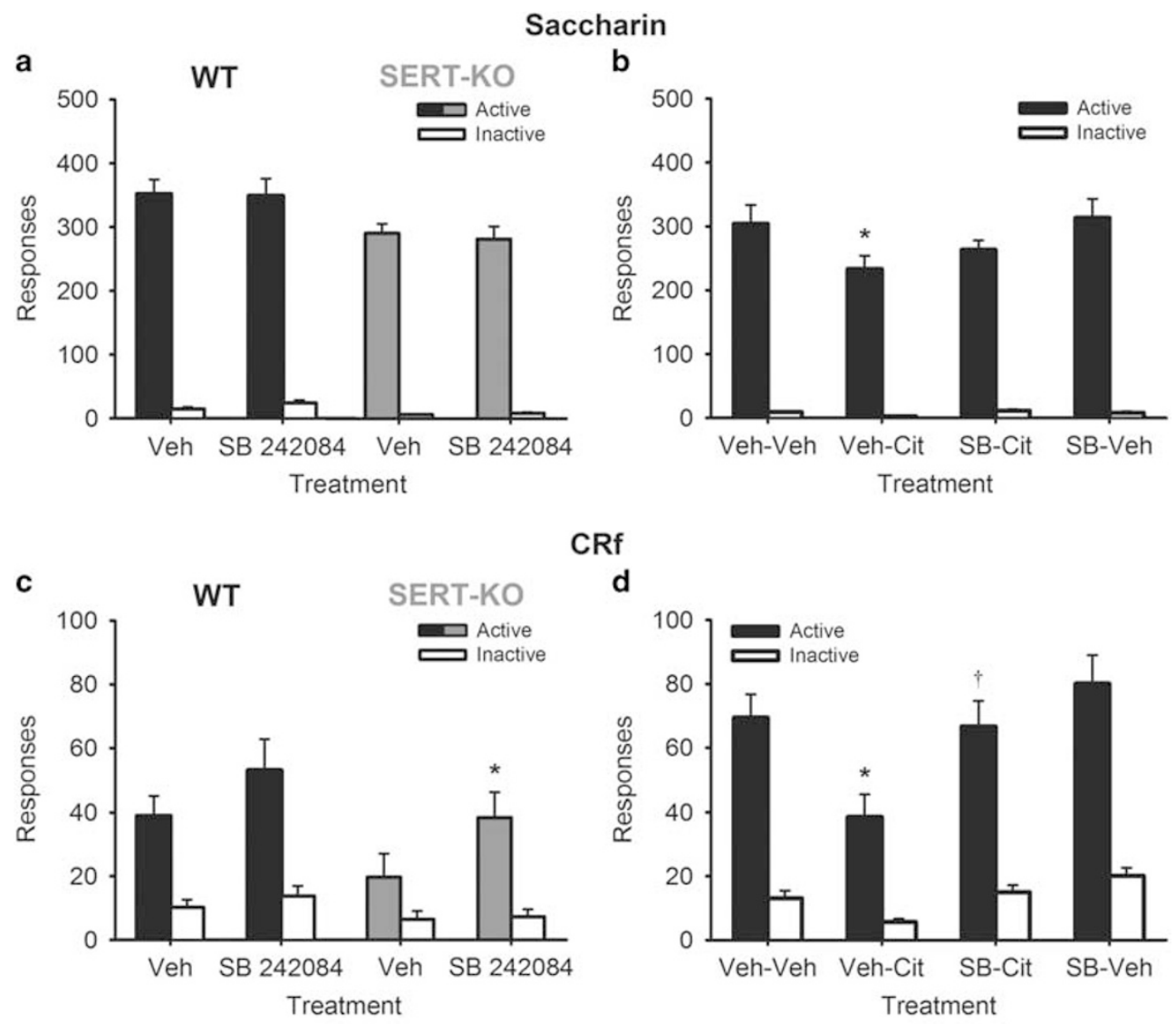

CRf
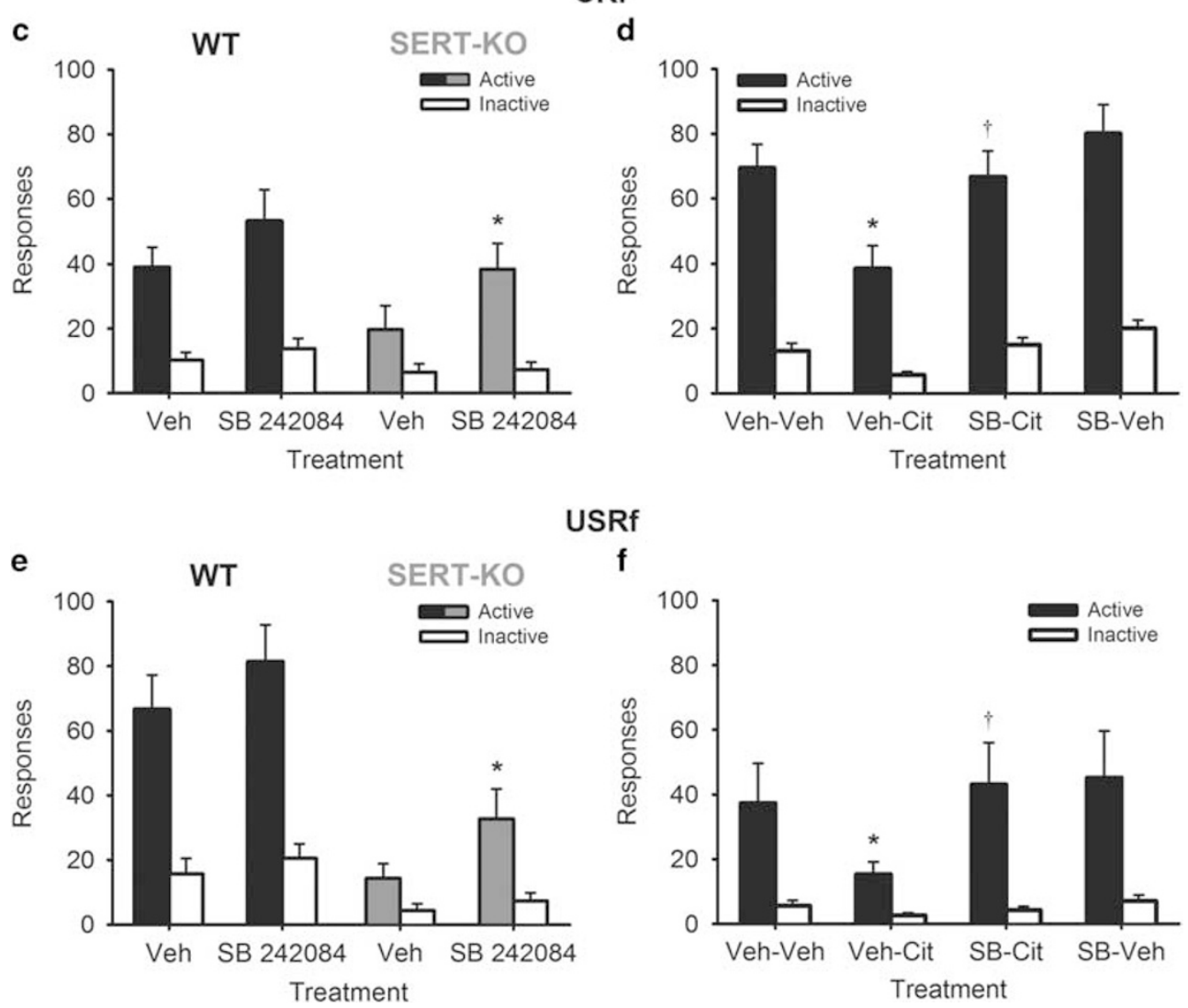

Figure 3 Blockade of the $5-\mathrm{HT}_{2 \mathrm{C}}$ receptor prevents the effects of SERT-KO and citalopram on responding for a conditioned reinforcer (CRf) and an unconditioned sensory reinforcer (USRf), but not for a primary reinforcer. Data are expressed in terms of the mean ( \pm SEM) number of responses on active lever (filled bars) or inactive lever (empty bars). Left panels (a, c, and e) depict responding for each reinforcer in SERT-KO mice and WT littermates following treatment with I mg/kg SB 242084 or its vehicle. Data in (e) reflect averaged values across three vehicle treatment sessions and five SB 242084 treatment sessions. Right panels (b, d, and f) show responding for each reinforcer in WT mice over four conditions wherein animals were treated with SB 242084 $(\mathrm{I} \mathrm{mg} / \mathrm{kg}$ in $\mathrm{b}$ and $\mathrm{f} ; 0.25 \mathrm{mg} / \mathrm{kg}$ in d) or its vehicle followed by citalopram ( $10 \mathrm{mg} / \mathrm{kg}$ ) or its vehicle. $* P<0.05$ vs vehicle or vs vehicle-vehicle conditions; ${ }^{\dagger} P<0.05$ vs vehicle-citalopram condition.

sessions. SB 242084 increased active lever responding in SERT-KO mice by $128 \%$ compared with vehicle (Figure 3e; Treatment $\times$ Lever: $\quad \mathrm{F}_{(1,} \quad{ }_{11)}=7.28, \quad p<0.05$; $\quad$ Treatment: $\left.\mathrm{F}_{(1,11)}=10.24, p<0.01\right)$, but had no effect in WT littermates (Treatment $\times$ Lever: $\mathrm{F}_{(1,11)}=2.35$, ns; Treatment: $\mathrm{F}_{(1,11)}=3.93$, ns). Treatment with $1 \mathrm{mg} / \mathrm{kg}$ SB 242084 completely blocked the ability of citalopram to decrease responding for a USRf (Figure 3f; $p<0.05$ ). The SB 242084-citalopram condition was significantly different from vehicle-citalopram $(p<0.001)$, but not vehicle-vehicle $(p>0.49)$.

\section{Experiment 4: Confirmation of SERT-KO and SERT-Selective Doses of Citalopram}

Figure 4 shows the effect of citalopram on responding for saccharin (a), a CRf (b), and a USRf (c) in SERT-KO mice 
a

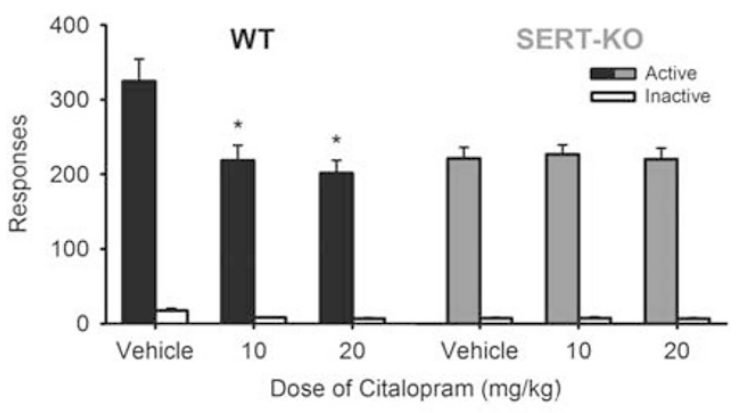

b

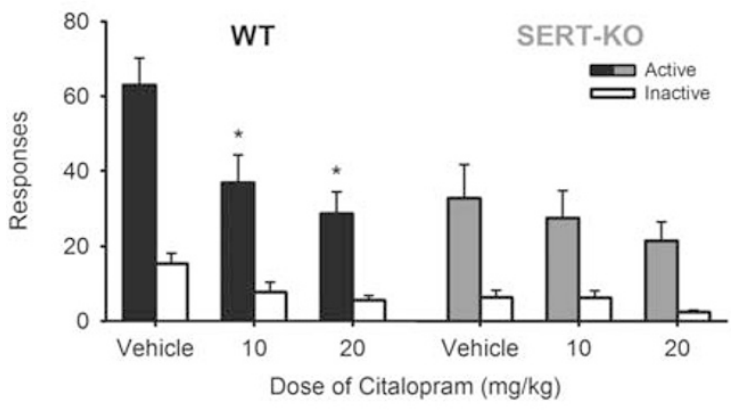

C

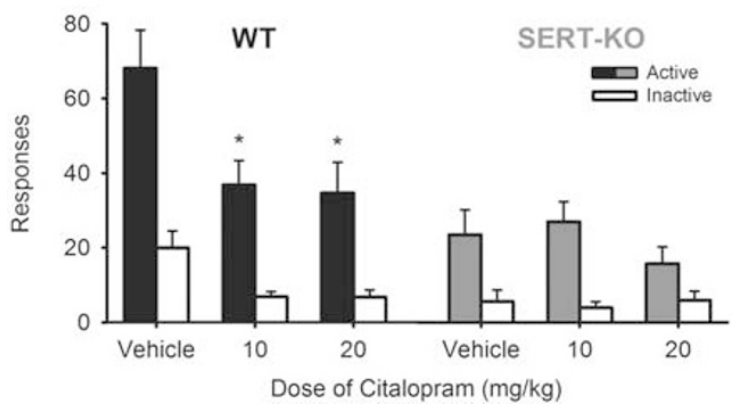

Figure 4 Confirmation of functional SERT-KO and the use of SERTselective doses of citalopram. (a) Responses made on the active lever delivering saccharin (filled bars) and the inactive lever (empty bars) in SERT$\mathrm{KO}$ mice and WT littermates on an RR4 schedule of reinforcement following treatment with 10 and $20 \mathrm{mg} / \mathrm{kg}$ citalopram or its vehicle. (b) Responses made on the active lever delivering the CRf (filled bars) and the inactive lever (empty bars) in SERT-KO mice and WT littermates on an RR2 schedule of reinforcement following treatment with 10 and $20 \mathrm{mg} / \mathrm{kg}$ citalopram or its vehicle. (c) Responses made on the active lever delivering the USRf (filled bars) and the inactive lever (empty bars) in SERT-KO mice and WT littermates on an RR2 schedule of reinforcement following treatment with 10 and $20 \mathrm{mg} / \mathrm{kg}$ citalopram or its vehicle. ${ }^{*} P<0.05$ vs vehicle.

and their WT littermates. Citalopram reduced responding for all three reinforcers in WT but not in SERT-KO mice (all Dose $\times$ Genotype interactions F $>7.99, p<0.01)$. Post hoc tests found that both 10 and $20 \mathrm{mg} / \mathrm{kg}$ citalopram decreased active lever responses for all three reinforcers in WT mice (all $p<0.001$ ), but SERT-KO mice were unaffected at either dose (all $p>0.34$ ).

\section{DISCUSSION}

The majority of evidence that 5-HT inhibits responding for various primary reinforcers has come from studies using acute pharmacological manipulations, such as treatment with dexfenfluramine or SSRIs. Genetic deletion of the SERT produces a selective 4- to 6-fold elevation in extracellular 5-HT levels (Bengel et al, 1998; Fabre et al, 2000; Shen et al, 2004), providing a selective method of examining how chronically elevated 5-HT contributes to behavior. In the present experiments, responding for the primary reinforcer saccharin was reduced in SERT-KO mice, consistent with findings from Sanders et al (2007) that SERT-KO mice exhibit reduced food-reinforced behavior.

In the Pavlovian conditioning phase of the conditioned reinforcement procedure, mice learned to approach the reward magazine when saccharin availability was signaled by a CS. This discriminated approach behavior suggests that animals learned the predictive significance of the CS. SERTKO mice and WT littermates acquired discriminated approach behavior at similar rates. However, compared with WT littermates, SERT-KO mice made fewer responses for the CS when it was subsequently used as a CRf. Together, these findings demonstrate that chronically elevated 5-HT does not alter associative stimulus-reward learning, but impairs the ability of a reward-associated stimulus to elicit incentive motivation.

SERT-KO mice consistently made fewer responses for a USRf throughout testing compared with WT littermates. Importantly, this lower responding in SERT-KO mice cannot be the result of a generalized learning deficit. In addition to exhibiting no impairments in stimulus-reward learning, SERT-KO mice readily acquired action-outcome contingencies based on their ability to respond for saccharin and a CRf. Furthermore, while responding was reduced, SERT-KO mice still demonstrated selective responding on the lever delivering the USRf.

Acute citalopram treatment at doses that selectively disrupted SERT function (Figure 4) greatly reduced responding for saccharin, a CRf, and a USRf. The findings from tests of responding for saccharin are consistent with previous reports that SSRIs and dexfenfluramine reduce responding for various primary reinforcers (Lee and Kornetsky, 1998; Richardson and Roberts, 1991; Thompson, 1977). Decreased responding for a CRf and USRf following citalopram treatment is also consistent with previous studies (Baker et al, 2001; Browne et al, 2016; Fletcher, 1995), further supporting the notion that acute elevation of 5-HT activity generally reduces the motivational significance of incentive stimuli.

The reinforcers used in these experiments elicited different levels of operant responding. This was most apparent when comparing response magnitudes for saccharin $v s$ a CRf or a USRf. From the ability of saccharin to elicit more appetitive behavior than a CRf or a USRf, it can be inferred that saccharin has a higher incentive value than a CRf or a USRf. This differential response magnitude has two important implications for interpreting the behavioral effects of elevated 5-HT activity.

The first implication is for considering whether the observed effects in SERT-KO mice are due to motor impairments. Previous studies have suggested that SERTKO mice exhibit reduced rotarod performance and locomotor activity (Holmes et al, 2002; Lira et al, 2003; Morelli et al, 2011). However, as previously suggested by Sanders et al (2007), motor incapacitation is an unlikely explanation for the lower operant response rate in SERT-KO mice. SERT-KO 
mice made substantially more responses (albeit at reduced level compared with WT controls) for saccharin than for a CRf and a USRf, and their responding for saccharin increased when the schedule of reinforcement was increased from RR2 to RR4 (see Figure 1). This suggests that SERT-KO mice can make more responses for each reinforcer, but that SERT disruption alters the ability of each reinforcer to elicit responding at levels comparable to WT animals.

The second implication is for interpreting the role of $5-\mathrm{HT}_{2 \mathrm{C}}$ receptors in mediating the effects of enhanced $5-\mathrm{HT}$ activity. Blockade of the $5-\mathrm{HT}_{2 \mathrm{C}}$ receptor was sufficient to reverse some effects of SERT-KO and prevent the effects of citalopram on responding for a CRf and a USRf. Conversely, $5-\mathrm{HT}_{2 \mathrm{C}}$ receptor blockade did not alter the effects of either manipulation on responding for saccharin. Therefore, the involvement of $5-\mathrm{HT}_{2 \mathrm{C}}$ receptors in mediating the effects of 5HT may scale with the incentive value of the stimulus: the higher the reinforcer value, the less specific involvement of 5$\mathrm{HT}_{2 \mathrm{C}}$.

The inability of SB 242084 to completely block the effects of elevated 5-HT on responding for saccharin may be related to the complexity of neurobiological mechanisms in place to control responding for highly valuable incentives. For example, feeding behavior is influenced by several neurotransmitters, neuromodulators, and peptides (Schwartz et al, 2000). In addition to the $5-\mathrm{HT}_{2 \mathrm{C}}$ receptor, $5-\mathrm{HT}_{1 \mathrm{~A}}$ and $5-\mathrm{HT}_{1 \mathrm{~B}}$ receptors have been implicated in the control of food intake, brain-stimulation reward, and the reinforcing properties of drugs of abuse (Dourish et al, 1986; Harrison et al, 1999; Lee et al, 2002; Montgomery et al, 1991; Peltier and Schenk, 1993; Rocha et al, 1998). Therefore, 5-HT may inhibit incentive motivation for highly valuable reinforcers through multiple receptor systems.

The present findings that $5-\mathrm{HT}_{2 \mathrm{C}}$ receptors do not mediate the inhibitory influence of elevated 5-HT on responding for saccharin appear to be at odds with many studies showing that $5-\mathrm{HT}_{2 \mathrm{C}}$ receptor agonists impair responding for food (Grottick et al, 2000; Wolff and Leander, 2000). One explanation for this disparity is that $5-\mathrm{HT}_{2 \mathrm{C}}$ receptor agonists may artificially drive $5-\mathrm{HT}_{2 \mathrm{C}}$ neurotransmission to a greater extent than is achieved through endogenous 5-HT activity. Nevertheless, the ability of SB 242084 to block the effects of SERT-KO and citalopram on responding for a CRf and a USRf is consistent with $5-\mathrm{HT}_{2 \mathrm{C}}$ receptor agonist studies (Guy and Fletcher, 2014; Neisewander and Acosta, 2007), and support a specific role for $5-\mathrm{HT}_{2 \mathrm{C}}$ receptors in these behaviors.

Serotonergic influences on incentive motivation may be mediated through interactions with the mesolimbic dopamine system. Dopamine neurons in the ventral tegmental area (VTA) are activated by reinforcing stimuli, and inhibiting dopamine action in the nucleus accumbens impairs rewardrelated behaviors (Schultz, 1998; Wise and Rompre, 1989). Manipulations of mesolimbic dopamine system activity alter all three behaviors measured in the present experiments (Olsen and Winder, 2009; Salamone and Correa, 2002; Taylor and Robbins, 1984). The VTA receives dense 5-HT innervation and exhibits high levels of $5-\mathrm{HT}_{2 \mathrm{C}}$ receptor expression (Bubar and Cunningham, 2007). Extensive electrophysiological and neurochemical findings demonstrate that $5-\mathrm{HT}_{2 \mathrm{C}}$ receptor agonists decrease mesolimbic dopamine system activity, while antagonists moderately increase accumbens dopamine release (Di Matteo et al, 2001). Therefore, 5-HT action at $5-\mathrm{HT}_{2 \mathrm{C}}$ receptors may reduce motivation by suppressing mesolimbic dopamine system activity.

The present results support the $5-\mathrm{HT}_{2 \mathrm{C}}$ receptor as a potential therapeutic target for treating disorders that present with dysregulated motivational processes, such as addiction, schizophrenia, and depression. The $5-\mathrm{HT}_{2 \mathrm{C}}$ receptor agonist lorcaserin reduces feeding behavior (Grottick et al, 2000) and has been approved for the treatment of obesity. However, the ability of lorcaserin to reduce motivation may extend to nonfood reinforcers: lorcaserin reduces responding for drugs of abuse such as cocaine and nicotine, and prevents reinstatement of responding for these drugs following periods of abstinence (as reviewed by Higgins et al, 2013). A recent study also demonstrates that the $5-\mathrm{HT}_{2 \mathrm{C}}$ receptor antagonist SB 242084 enhances motivation under certain circumstances (Bailey et al, 2015). Consistent with this, the present experiments demonstrate that some 5-HT-mediated deficits in incentive motivation can be reversed by treatment with SB 242084. Therefore, the $5-\mathrm{HT}_{2 \mathrm{C}}$ receptor may be a bidirectional therapeutic target for dysregulated motivation: $5-\mathrm{HT}_{2 \mathrm{C}}$ receptor agonists could be used to treat pathologically high motivation (eg, in addiction), while $5-\mathrm{HT}_{2 \mathrm{C}}$ receptor antagonists could potentially be used to treat pathologically low motivation (eg, in depression).

In conclusion, these experiments demonstrate that 5-HT activity broadly reduces incentive motivation irrespective of reinforcer identity or value. However, the $5-\mathrm{HT}_{2 \mathrm{C}}$ receptor mediates the effects of 5-HT in a reinforcer-dependent manner; $5-\mathrm{HT}_{2 \mathrm{C}}$ signaling reduces the motivation elicited by a reinforcer based on its incentive value. Together, these results bridge the gap between parallel lines of research examining the effects of $5-\mathrm{HT}$ itself and $5-\mathrm{HT}_{2 \mathrm{C}}$ agonists on incentive motivation, and support a powerful role for 5-HT in the inhibitory control of motivated behavior.

\section{FUNDING AND DISCLOSURE}

The authors declare no conflict of interest.

\section{ACKNOWLEDGMENTS}

We thank Katrina Deverell for her invaluable assistance maintaining animal colonies, and Dr Fiona D. Zeeb, Dr Junchul Kim, and Dr Suzanne Erb for their helpful comments on some of this work. This research was supported by a Doctoral award from the Natural Sciences and Engineering Research Council of Canada to CJB and a Canadian Institutes of Health Research operating grant to PJF.

\section{REFERENCES}

Bailey MR, Williamson C, Mezias C, Winiger V, Silver R, Balsam PD et al (2015). The effects of pharmacological modulation of the serotonin 2C receptor on goal-directed behavior in mice. Psychopharmacology (Berl) 233: 615-624.

Baker DA, Tran-Nguyen LTL, Fuchs RA, Neisewander JL (2001). Influence of individual differences and chronic fluoxetine treatment on cocaine-seeking behavior in rats. Psychopharmaco$\log y$ (Berl) 155: 18-26.

Barnes NM, Sharp T (1999). A review of central 5-HT receptors and their function. Neuropharmacology 38: 1083-1152. 
Bengel D, Murphy DL, Andrews AM, Wichems CH, Feltner D, Heils A et al (1998). Altered brain serotonin homeostasis and locomotor insensitivity to 3, 4-methylenedioxymethamphetamine ('Ecstasy') in serotonin transporter-deficient mice. Mol Pharmacol 53: 649-655.

Beninger RJ, Ranaldi R (1992). The effects of amphetamine, apomorphine, SKF 38393, quinpirole and bromocriptine on responding for conditioned reward in rats. Behav Pharmacol 3: 155-163.

Browne CJ, Fletcher PJ, Zeeb FD (2016). Responding for a conditioned reinforcer or unconditioned sensory reinforcer in mice: interactions with environmental enrichment, social isolation, and monoamine reuptake inhibitors. Psychopharmacology (Berl) 233: 983-993.

Browne JDC, Soko AD, Fletcher PJ (2014). Responding for conditioned reinforcement in C57BL/6 and CD-1 mice, and Sprague-Dawley rats: Effects of methylphenidate and amphetamine. Psychopharmacology (Berl) 231: 4503-4516.

Bubar MJ, Cunningham KA (2007). Distribution of serotonin 5 -HT2C receptors in the ventral tegmental area. Neuroscience 146: 286-297.

Burmeister JJ, Lungren EM, Neisewander JL (2003). Effects of fluoxetine and d-fenfluramine on cocaine-seeking behavior in rats. Psychopharmacology (Berl) 168: 146-154.

Carroll ME, Lac ST, Asencio M, Kragh R (1990). Fluoxetine reduces intravenous cocaine self-administration in rats. Pharmacol Biochem Behav 35: 237-244.

Cunningham KA, Fox RG, Anastasio NC, Bubar MJ, Stutz SJ, Moeller FG et al (2011). Selective serotonin 5-HT2C receptor activation suppresses the reinforcing efficacy of cocaine and sucrose but differentially affects the incentive-salience value of cocaine- vs. sucrose-associated cues. Neuropharmacology 61: 513-523.

Di Matteo V, De Blasi A, Di Giulio C, Esposito E (2001). Role of 5$\mathrm{HT} 2 \mathrm{C}$ receptors in the control of central dopamine function. Trends Pharmacol Sci 22: 229-232.

Dourish CT, Hutson PH, Kennett GA, Curzon G (1986). 8-OHDPAT-induced hyperphagia: its neural basis and possible therapeutic relevance. Appetite 7 Suppl: 127-140.

Fabre V, Beaufour C, Evrard A, Rioux A, Hanoun N, Lesch KP et al (2000). Altered expression and functions of serotonin 5-HT1A and 5-HT1B receptors in knock-out mice lacking the 5-HT transporter. Eur J Neurosci 12: 2299-2310.

Fletcher PJ (1995). Effects of d-fenfluramine and metergoline on responding for conditioned reward and the response potentiating effect of nucleus accumbens d-amphetamine. Psychopharmacology (Berl) 118: 155-163.

Fletcher PJ, Korth KM, Chambers JW (1999). Selective destruction of brain serotonin neurons by 5,7-dihydroxytryptamine increases responding for a conditioned reward. Psychopharmacology (Berl) 147: 291-299.

Fletcher PJ, Rizos Z, Noble K, Soko AD, Silenieks LB, Lê AD et al (2012). Effects of the 5-HT2C receptor agonist Ro60-0175 and the 5HT2A receptor antagonist M100907 on nicotine self-administration and reinstatement. Neuropharmacology 62: 2288-2298.

Grottick AJ, Fletcher PJ, Higgins GA (2000). Studies to investigate the role of 5-HT(2C) receptors on cocaine- and food-maintained behavior. J Pharmacol Exp Ther 295: 1183-1191.

Guy EG, Fletcher PJ (2014). Responding for a conditioned reinforcer, and its enhancement by nicotine, is blocked by dopamine receptor antagonists and a 5-HT2C receptor agonist but not by a 5-HT2A receptor antagonist. Pharmacol Biochem Behav 125: 40-47.

Harrison AA, Parsons LH, Koob GF, Markou A (1999). RU 24969, a 5-HT(1A/1B) agonist, elevates brain stimulation reward thresholds: an effect reversed by GR 127935, a 5-HT(1B/1D) antagonist. Psychopharmacology (Berl) 141: 242-250.

Higgins GA, Sellers EM, Fletcher PJ (2013). From obesity to substance abuse: therapeutic opportunities for 5-HT2C receptor agonists. Trends Pharmacol Sci 34: 560-570.
Holmes A, Yang RJ, Murphy DL, Crawley JN (2002). Evaluation of antidepressant-related behavioral responses in mice lacking the serotonin transporter. Neuropsychopharmacology 27: 914-923.

Kelley AE, Delfs JM (1991). Dopamine and conditioned reinforcement. I. Differential effects of amphetamine microinjections into striatal subregions. Psychopharmacology (Berl) 103: 187-196.

Lee K, Kornetsky C (1998). Acute and chronic fluoxetine treatment decreases the sensitivity of rats to rewarding brain stimulation. Pharmacol Biochem Behav 60: 539-544.

Lee MD, Kennett GA, Dourish CT, Clifton PG (2002). 5-HT1B receptors modulate components of satiety in the rat: behavioural and pharmacological analyses of the selective serotonin1B agonist CP-94,253. Psychopharmacology (Berl) 164: 49-60.

Lira A, Zhou M, Castanon N, Ansorge MS, Gordon JA, Francis JH et al (2003). Altered depression-related behaviors and functional changes in the dorsal raphe nucleus of serotonin transporterdeficient mice. Biol Psychiatry 54: 960-971.

Lyness WH, Friedle NM, Moore KE (1980). Increased selfadministration of d-amphetamine after destruction of 5-hydroxytryptaminergic neurons. Pharmacol Biochem Behav 12: 937-941.

Manvich DF, Kimmel HL, Howell LL (2012). Effects of serotonin $2 \mathrm{C}$ receptor agonists on the behavioral and neurochemical effects of cocaine in squirrel monkeys. J Pharmacol Exp Ther 341: 424-434.

McClelland RC, Sarfaty T, Hernandez L, Hoebel BG (1989). The appetite suppressant, d-fenfluramine, decreases self-stimulation at a feeding site in the lateral hypothalamus. Pharmacol Biochem Behav 32: 411-414.

Mead AN, Stephens DN (2003). Involvement of AMPA receptor GluR2 subunits in stimulus-reward learning: evidence from glutamate receptor gria2 knock-out mice. J Neurosci 23: 9500-9507.

Montgomery AM, Rose IC, Herberg LJ (1991). 5-HT1A agonists and dopamine: the effects of 8-OH-DPAT and buspirone on brain-stimulation reward. J Neurl Transm Gen Sect 63: 139-148.

Morelli E, Moore H, Rebello TJ, Gray N, Steele K, Esposito E et al (2011). Chronic 5-HT transporter blockade reduces DA signaling to elicit basal ganglia dysfunction. J Neurosci 31: 15742-15750.

Neisewander JL, Acosta JI (2007). Stimulation of 5-HT2C receptors attenuates cue and cocaine-primed reinstatement of cocaineseeking behavior in rats. Behav Pharmacol 18: 791-800.

Olsen CM, Winder DG (2009). Operant sensation seeking engages similar neural substrates to operant drug seeking in C57 mice. Neuropsychopharmacology 34: 1685-1694.

Peltier R, Schenk S (1993). Effects of serotonergic manipulations on cocaine self-administration in rats. Psychopharmacology (Berl) 110: $390-394$

Poschel BP, Ninteman FW (1971). Intracranial reward and the forebrain's serotonergic mechanism: studies employing parachlorophenylalanine and para-chloroamphetamine. Physiol Behav 7: 39-46.

Richardson NR, Roberts DC (1991). Fluoxetine pretreatment reduces breaking points on a progressive ratio schedule reinforced by intravenous cocaine self-administration in the rat. Life Sci 49: 833-840.

Rocha BA, Scearce-Levie K, Lucas JJ, Hiroi N, Castanon N, Crabbe JC et al (1998). Increased vulnerability to cocaine in mice lacking the serotonin-1B receptor. Nature 393: 175-178.

Salamone JD, Correa M (2002). Motivational views of reinforcement: implications for understanding the behavioral functions of nucleus accumbens dopamine. Behav Brain Res 137: 3-25.

Sanders AC, Hussain AJ, Hen R, Zhuang X (2007). Chronic blockade or constitutive deletion of the serotonin transporter reduces operant responding for food reward. Neuropsychopharmacology 32: 2321-2329.

Schultz W (1998). Predictive reward signal of dopamine neurons. J Neurophysiol 80: 1-27. 
Schwartz MW, Woods SC, Porte D, Seeley RJ, Baskin DG (2000). Central nervous system control of food intake. Nature 404: 661-671.

Shen H-W, Hagino Y, Kobayashi H, Shinohara-Tanaka K, Ikeda K, Yamamoto $\mathrm{H}$ et al (2004). Regional differences in extracellular dopamine and serotonin assessed by in vivo microdialysis in mice lacking dopamine and/or serotonin transporters. Neuropsychopharmacology 29: 1790-1799.

Stewart J (1960). Reinforcing effects of light as a function of intensity and reinforcement schedule. J Comp Physiol Psychol 53: 187-193.

Taylor JR, Robbins TW (1984). Enhanced behavioural control by conditioned reinforcers following microinjections of d-amphetamine into the nucleus accumbens. Psychopharmacology (Berl) 84: 405-412.

Taylor JR, Robbins TW (1986). 6-Hydroxydopamine lesions of the nucleus accumbens, but not of the caudate nucleus, attenuate enhanced responding with reward-related stimuli produced by intraaccumbens d-amphetamine. Psychopharmacology (Berl) 90: 390-397.

Thompson DM (1977). Effects of cocaine and fenfluramine on progressive-ratio performance. Pharmacol Biochem Behav 7: $555-558$.
Tomkins DM, Joharchi N, Tampakeras M, Martin JR, Wichmann J, Higgins GA (2002). An investigation of the role of 5-HT(2C) receptors in modifying ethanol self-administration behaviour. Pharmacol Biochem Behav 71: 735-744.

Wilson AW, Costall B, Neill JC (2000). Manipulation of operant responding for an ethanol-paired conditioned stimulus in the rat by pharmacological alteration of the serotonergic system. J Psychopharmacol 14: 340-346.

Wise R, Rompre PP (1989). Brain dopamine and reward. Annu Rev Psychol 40: 191-225.

Wogar MA, Bradshaw CM, Szabadi E (1991). Evidence for an involvement of 5-hydroxytryptaminergic neurones in the maintenance of operant behaviour by positive reinforcement. Psychopharmacology (Berl) 105: 119-124.

Wolff MC, Leander JD (2000). A comparison of the behavioural effects of 5-HT2A and 5-HT2C receptor agonists in the pigeon. Behav Pharmacol 11: 355-364.

Zeeb FD, Higgins GA, Fletcher PJ (2015). The serotonin 2C receptor agonist lorcaserin attenuates intracranial self-stimulation and blocks the reward-enhancing effects of nicotine. ACS Chem Neurosci 6: 1231-1240. 